\title{
PENERAPAN MODEL PEMBELAJARAN KOOPERATIF NHT UNTUK MENINGKATKAN HASIL BELAJAR MATEMATIKA SISWA XI IPS 5 SMAN 12 PEKANBARU
}

\author{
Alfarobi $^{1)}$, Alirman ${ }^{2)}$ \\ ${ }^{1)}$ Pendidikan Matematikan, Universitas Riau \\ ${ }^{2)}$ SMA Negeri 12 Pekanbaru \\ Email : alfarobi90@gmail.com
}

\begin{abstract}
Abstrak. Penelitian ini merupakan penelitian tindakan kelas yang bertujuan untuk meningkatkan hasil belajar matematika siswa kelas XI IPS 5 SMA Negeri 12 Pekanbaru melalui model pembelajaran kooperatif tipe Numbered Heads Together (NHT) pada semester genap tahun pelajaran 2018/2019. Subjek penelitian adalah siswa kelas XI IPS 5 yang berjumlah 35 orang dengan kemampuan akademik yang heterogen. Pengumpulan data dilakukan melalui pengamatan dan tes hasil belajar matematika. Pengamatan dilakukan oleh satu orang guru matematika SMAN 12 dan satu orang dosen Pendidikan Matematika FKIP UNRI. Tes hasil belajar matematika dilakukan sebanyak dua kali di setiap akhir siklus. Instrumen pengumpulan data yang digunakan adalah lembar pengamatan aktifitas guru dan siswa serta soal tes hasil belajar matematika. Data aktifitas guru dan siswa dianalisis secara kualitatif dan data hasil belajar matematika dianalisis secara kuantitatif. Hasil penelitian menunjukkan bahwa aktifitas guru dalam menerapkan pembelajaran kooperatif tipe NHT sudah semakin sesuai dengan RPP dan mengalami peningkatan kualitas untuk setiap pertemuan. Demikian juga halnya dengan aktifitas siswa yang menunjukkan kemajuan untuk setiap pertemuan. Siswa sudah berani untuk maju ke depan kelas mempresentasikan hasil diskusi kelompoknya. Sejalan dengan peningkatan aktifitas guru dan siswa dalam pembelajaran, hasil belajar matematika siswa juga meningkat. Persentase siswa yang mencapai Kriteria Ketuntasan Minimal (KKM) untuk siklus I dan II adalah 14,28\%, naik 8,58\% sebelum dilakukan tindakan. Dengan demikian dapat disimpulkan bahwa terjadi peningkatan hasil belajar matematika dengan menerapkan model pembelajaran kooperatif tipe NHT.
\end{abstract}

Kata Kunci : Hasil belajar matematika, Model Pembelajaran kooperatif tipe NHT, Penelitian Tindakan Kelas

\section{PENDAHULUAN}

Kehadiran revolusi industri 4.0 membuat dunia mengalami perubahan yang semakin cepat dan kompetitif. Untuk menghadapi itu, Menteri Pendidikan dan Kebudayaan Muhadjir Effendy (Febrianto, 2018) menilai perlu merevisi kurikulum dengan menambahkan lima kompetensi, yaitu diharapkan siswa memiliki kemampuan berpikir kritis, diharapkan siswa memiliki kreatifitas dan kemampuan yang inovatif, perlu adanya kemampuan dan keterampilan berkomunikasi yang dimiliki oleh siswa, bekerja sama dan berkolaborasi, serta diharapkan siswa memiliki kepercayaan diri. Sejalan dengan pendapat Mendikbud, Menteri Keuangan Sri Mulyani (Kiwari, 2018) mengatakan bahwa penguasaan matematika diperlukan untuk mengelola ekonomi negara terlebih dalam menghadapi era revolusi industri 4.0, karena peranan matematika sangat besar dalam memahami fenomena baru yang lahir dari kebutuhan fintech dan digital economy secara luas. Oleh karena itu, sangat penting untuk siswa menguasai matematika di sekolah dalam menghadapi revolusi industri 4.0 dan menghadapi problematika yang akan terjadi di masa depan. Penguasaan matematika siswa di sekolah dapat dilihat dari hasil belajar matematika siswa.

Hasil belajar matematika pada kurikulum 2013 mengharuskan siswa untuk mencapai Standar Kompetensi Lulusan (SKL) yang meliputi ranah sikap, pengetahuan, dan keterampilan. Ketuntasan hasil belajar merupakan tingkat minimal pencapaian kompetensi sikap, pengetahuan, dan keterampilan. Ketuntasan hasil belajar tersebut dapat dilihat dari ketuntasan siswa pada setiap Kompetensi Dasar (KD) serta memenuhi Kriteria Ketuntasan Minimum (KKM) yang ditetapkan. KKM adalah kriteria ketuntasan belajar yang ditentukan oleh satuan pendidikan yang mengacu pada standar kompetensi kelulusan, dengan mempertimbangkan karakteristik siswa, karakteristik mata 
pelajaran, dan kondisi satuan pendidikan (Permendikbud No. 23 tahun 2016). Ketercapaian KKM setiap kompetensi dasar dianalisis dari hasil penilaian harian setiap siklus yang dilakukan oleh guru.

Kenyataaan yang terjadi di lapangan menunjukkan bahwa hasil belajar matematika siswa masih rendah. Berdasarkan wawancara yang dilakukan dengan guru matematika kelas XI IPS 5 SMA Negeri 12 Pekanbaru pada semester genap tahun pelajaran 2018/2019, diperoleh informasi bahwa masih banyak siswa di kelas tersebut yang belum mencapai KKM yang ditetapkan sekolah yaitu 75. Penilaian harian pada KD 3.7 Menjelaskan limit fungsi aljabar (fungsi polinom dan fungsi rasional) secara intuitif dan sifat-sifatnya, serta menentukan eksistensinya dan KD 4.7 Menyelesaikan masalah yang berkaitan dengan limit fungsi aljabar, jumlah siswa yang mencapai KKM adalah 2 siswa dari 35 siswa $(5,7 \%)$.

Untuk mengetahui permasalahan yang terjadi dalam pembelajaran, peneliti melakukan pengamatan terhadap proses pembelajaran matematika di kelas XI IPS 5 SMA Negeri 12 Pekanbaru, dan didapatkan fakta bahwa:

1. Kebanyakan siswa kurang aktif dalam proses pembelajaran matematika.

2. Siswa kurang bertanggung jawab dalam menyelesaikan tugas yang diberikan dalam proses pembelajaran. Hal ini diperkuat dari penjelasan guru ketika siswa diberi latihan kebanyakan siswa lebih cenderung melihat atau menunggu punya temannya yang sudah selesai mengerjakan.

3. Pada saat presentasi kelompok, siswa yang presentasi yang menjawab pertanyaan guru, sehingga ada dominasi siswa yang berkemampuan tinggi

4. Kurangnya rasa ingin tahu siswa terhadap materi pembelajaran. Hal ini diperkuat oleh penjelasan guru bahwa siswa lebih cenderung diam atau mengobrol dengan temannya daripada memahami materi pembelajaran.

5. Pemahaman siswa terhadap materi masih kurang

Dari hasil wawancara dan pengamatan, peneliti menyimpulkan bahwa perlu diterapkannya suatu model pembelajaran yang melibatkan peran siswa secara aktif dalam kegiatan pembelajaran sehingga dapat meningkatkan hasil belajar matematika. Model pembelajaran yang dapat melibatkan peran siswa secara aktif salah satunya adalah pembelajaran kooperatif. Pada pembelajaran kooperatif ini, siswa lebih aktif dalam berbicara dan berpendapat. Menurut Slavin (2010), melalui model pembelajaran ini siswa dapat mengemukakan pemikirannya, saling bertukar pendapat, saling bekerjasama jika ada teman dalam kelompoknya yang kesulitan untuk memahami materi. Selain itu juga dapat menumbuhkan rasa sadar kepada siswa bahwasanya para siswa perlu belajar untuk berpikir menyelesaikan masalah dan mengintegrasikan serta mengaplikasikan kemampuan dan pengetahuan mereka. Penerapan pembelajaran kooperatif merupakan bentuk perubahan pola pikir dalam kegiatan belajar mengajar di sekolah. Guru tidak lagi mendominasi kegiatan pembelajaran. Guru lebih banyak menjadi fasilitator dan mediator pada proses pembelajaran. Pembelajaran kooperatif dirancang dengan memberikan kesempatan kepada siswa secara bersama-sama untuk membangun pengetahuannya sendiri. Pada model pembelajaran kooperatif terdapat enam fase, yang disajikan pada tabel berikut.

Tabel 1. Fase Model Pembelajaran Kooperatif

\begin{tabular}{|c|c|}
\hline Fase & Tingkah laku guru \\
\hline $\begin{array}{l}\text { 1. Menyampaikan } \\
\text { tujuan dan } \\
\text { memotivasi } \\
\text { siswa }\end{array}$ & $\begin{array}{l}\text { Guru menyampaikan } \\
\text { semua tujuan } \\
\text { pembelajaran yang } \\
\text { ingin dicapai pada } \\
\text { pembelajaran tersebut } \\
\text { dan memotivasi siswa } \\
\text { belajar }\end{array}$ \\
\hline $\begin{array}{l}\text { 2. Menyajikan } \\
\text { informasi }\end{array}$ & $\begin{array}{l}\text { Guru menyajikan } \\
\text { informasi kepada } \\
\text { siswa dengan jalan } \\
\text { demonstrasi atau lewat } \\
\text { bahan bacaan }\end{array}$ \\
\hline $\begin{array}{l}\text { 3. Mengorganisasi } \\
\text { siswa ke dalam } \\
\text { kelompok- } \\
\text { kelompok } \\
\text { belajar }\end{array}$ & $\begin{array}{l}\text { Guru menjelaskan } \\
\text { kepada siswa } \\
\text { bagaimana caranya } \\
\text { membuat kelompok } \\
\text { belajar dan membantu } \\
\text { setiap kelompok agar } \\
\text { melakukan transisi } \\
\text { secara efesien }\end{array}$ \\
\hline $\begin{array}{l}\text { 4. Membimbing } \\
\text { kelompok } \\
\text { bekerja dan }\end{array}$ & $\begin{array}{l}\text { Guru membimbing } \\
\text { kelompok-kelompok } \\
\text { belajar pada saat }\end{array}$ \\
\hline
\end{tabular}


PRINSIP Pendidikan Matematika

Volume 1, Nomor 2, Mei 2019

\begin{tabular}{cl}
\hline \multicolumn{1}{c}{ Fase } & Tingkah laku guru \\
\hline belajar & $\begin{array}{l}\text { mereka mengerjakan } \\
\text { tugas }\end{array}$ \\
\hline & $\begin{array}{l}\text { Guru mengevaluasi } \\
\text { hasil belajar tentang } \\
\text { materi yang telah } \\
\text { dipelajari atau masing- } \\
\text { masing kelompok } \\
\text { mempresentasikan } \\
\text { 5. Evaluasi }\end{array}$ \\
& $\begin{array}{l}\text { Guru mencari cara- } \\
\text { cara untuk menghargai } \\
\text { baik upaya maupun } \\
\text { hasil belajar individu } \\
\text { dan kelompok }\end{array}$ \\
\hline
\end{tabular}

Sumber : Ibrahim dan Nur (2000)

Slavin (2010) mengemukakan ada tiga kendala yang disebut pitfalls (lubang-lubang perangkap) terkait dalam pembelajaran kooperatif yaitu sebagai berikut.

1. Pengendara bebas

Maksud pengendara bebas disini adalah beberapa siswa yang tidak bertanggung jawab secara personal terhadap tugas kelompoknya. Mereka hanya mengikuti saja apa yang dilakukan teman-teman satu kelompoknya yang lain. Pegendara bebas ini sering kali muncul ketika kelompokkelompok kooperatif ditugaskan untuk menangani lembar kerja, satu proyek, atau suatu laporan tertentu. Untuk tugas-tugas seperti ini seringkali ada satu atau beberapa anggota yang mengerjakan hampir semua pekerjaan kelompoknya, sementara sebagian anggota yang lain, bebas berkeliaran kemana-mana.

2. Diffusing of responsibility atau penyebaran tanggung jawab

Ini adalah suatu kondisi di mana beberapa anggota yang dianggap tidak mampu cenderung diabaikan oleh anggota-anggota yang lebih mampu.

3. Setiap kelompok ditugaskan untuk mempelajari atau mengerjakan tugas bagian materi yang berbeda antara kelompok satu dan kelompok yang lainnya sehingga kelompok hanya terfokus dengan materi yang kelompoknya dapatkan dan cenderung menghiraukan materi yang lain yang dipelajari oleh kelompok lain, padahal semua materi tersebut saling

berkaitan antara materi satu dan materi yang lainya.

Salah satu solusi mengatasi kelemahan pembelajaran kooperatif adalah dengan mengintegrasikan model pembelajaran atau metode yang satu dengan yang lain (Slavin 2010). Salah satu tipe model pembelajaran kooperatif adalah tipe Numbered Heads Together (NHT). Pembelajaran kooperatif tipe NHT lebih menekankan pada pola interaksi siswa yang bertujuan untuk meningkatkan penguasaan akademik setiap siswa. Siswa di tempatkan dalam tim belajar yang heterogen yang beranggotakan 3-5 orang. Kemudian masing-masing siswa dalam kelompok diberi nomor urut sesuai identitas di dalam kelompoknya. Adanya penunjukan secara acak kepada setiap anggota kelompok dalam memberikan jawaban yang diajukan oleh guru membuat semua kelompok memastikan teman sekelompoknya memahami materi yang diberikan dalam lembar kerja. Kondisi ini tentu akan mempengaruhi interaksi antar kelompok yang lebih aktif sehingga berdampak baik pada pemahaman siswa tentang materi pelajaran, sehingga diharapkan dapat meningkatkan hasil belajar matematika.

Lie (2007) memaparkan langkah-langkah pembelajaran kooperatif tipe NHT yaitu sebagai berikut:

1. Siswa dibagi menjadi beberapa kelompok. Setiap siswa di masing-masing kelompok mendapatkan nomor.

2. Guru memberikan tugas dan masingmasing kolompok mengerjakannya.

3. Kelompok memutuskan jawaban yang dianggap paling benar dan memastikan setiap anggota kelompok mengetahui jawaban ini.

4. Guru memanggil salah satu nomor. Siswa dengan nomor yang dipanggil melaporkan hasil kerja mereka.

Menurut Kunarsih dan Berlin (2016) bahwa model pembelajaran kooperatif tipe NHT memiliki beberapa kelebihan, yaitu dapat meningkatkan prestasi siswa, mampu memperdalam pemahaman siswa, melatih tanggung jawab siswa, mempermudah siswa dalam belajar, membangun rasa ingin tahu siswa, meningkatkan rasa percaya diri siswa, mengembangkan rasa memiliki dan kerja sama, setiap siswa termotivasi untuk menguasai materi, menghilangkan kesenjangan antara yang 
pintar dan yang kurang pintar dan terciptanya suasana gembira dalam belajar.

\section{METODE}

Penelitian ini merupakan Penelitian Tindakan Kelas (PTK). Arikunto, dkk (2012) menyatakan bahwa penelitian tindakan kelas merupakan pencermatan terhadap kegiatan belajar berupa sebuah tindakan yang sengaja dimunculkan dan terjadi dalam sebuah kelas secara bersama. Bentuk penelitian tindakan kelas dalam penelitian ini dilakukan secara kolaboratif, yaitu peneliti dan guru bekerja sama dalam proses pelaksanaan tindakan. Pelaksanaan tindakan dilakukan oleh peneliti, sedangkan guru matematika kelas XI IPS 5 SMAN 12 Pekanbaru bertindak sebagai pengamat. Tindakan yang dilakukan adalah penerapan model kooperatif tipe NHT. Subjek penelitian adalah siswa kelas XI IPS 5 SMAN 12 Pekanbaru semester genap tahun pelajaran 2018/2019 yang berjumlah 35 orang dengan kemampuan akademik yang heterogen.

Selanjutnya Arikunto, dkk (2012) menyatakan bahwa secara garis besar PTK dilaksanakan melalui empat tahap yang lazim dilalui, yaitu perencanaan, pelaksanaan, pengamatan, dan refleksi. Berpandu pada pernyataan Arikunto di atas, model siklus penelitian tindakan kelas yang digunakan pada penelitian ini disajikan pada Gambar1.

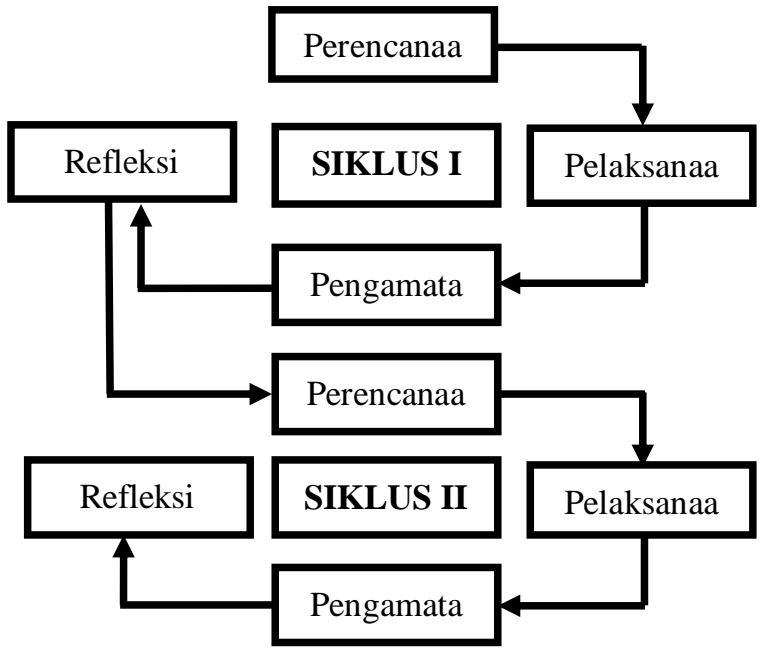

Gambar1. Siklus Penelitian Tindakan Kelas

Penelitian tindakan kelas ini dilaksanakan dalam dua siklus yaitu siklus I dilaksanakan selama enam pertemuan dan siklus II dilaksanakan selama empat pertemuan.
Setiap siklus dilaksanakan sesuai dengan perencanaan yang telah ditentukan untuk mencapai tujuan yang diinginkan, dimana antara siklus I dan siklus II merupakan rangkaian kegiatan yang saling berkaitan.

Teknik pengumpulan data yang dilakukan adalah pengamatan aktifitas guru dan siswa selama pembelajaran dan tes hasil belajar matematika yang dilakukan di setiap akhir siklus. Pengamatan dilakukan dengan menggunakan lembar pengamatan aktifitas guru dan lembar pengamatan aktifitas siswa. Tes hasil belajar dilakukan secara tertulis dengan menggunakan soal berbentuk uraian.

Data aktifitas guru dan siswa dianalisis secara kualitatif untuk melihat aktifitas-aktifitas pada proses pembelajaran yang belum maksimal pelaksanaannya. Analisis data kualitatif bertujuan untuk melihat proses perbaikan pembelajaran. Analisis ini dilakukan dengan cara membandingkan setiap langkah pembelajaran yang termuat di RPP dengan implementasi pembelajaran pada setiap pertemuan. Terjadinya perbaikan pada proses pembelajaran apabila kualitas setiap langkah pembelajaran semakin membaik setiap pertemuannya.

Teknik analisis data hasil belajar matematika siswa adalah analisis statistik deskriptif. Statistik deskriptif adalah statistik yang mempunyai tugas mengorganisasikan dan menganalisis data angka, agar dapat memberikan gambaran secara teratur, ringkas, dan jelas mengenai suatu gejala, peristiwa atau keadaan, sehingga dapat ditarik pengertian atau makna (Sudijono, 2009). Analisis data mengenai ketercapaian hasil belajar matematika siswa dilakukan dengan melihat hasil belajar siswa secara individu. Data hasil belajar matematika siswa dianalisis berdasarkan ketercapaian KKM. Analisis data tentang ketercapaian KKM dilakukan dengan membandingkan persentase jumlah siswa yang mencapai KKM pada skor dasar dengan jumlah siswa yang mencapai KKM pada tes hasil belajar matematika setelah menerapkan model pembelajaran kooperatif tipe NHT. KKM yang ditetapkan oleh sekolah yaitu 75. Siswa dikatakan tuntas jika mencapai nilai $\geq 75$ pada Penilaian Harian I dan Penilaian Harian II. Persentase jumlah siswa yang mencapai KKM dapat dihitung dengan rumus sebagai berikut. 


$$
P=\frac{J S K}{J S S} \times 100 \%
$$

Keterangan:

$$
\mathrm{P}=\text { Persentase siswa yang mencapai }
$$
KKM

JSK = Jumlah siswa mencapai KKM

JSS = Jumlah siswa seluruhnya

Hasil belajar matematika dikatakan meningkat apabila persentase jumlah siswa yang mencapai KKM meningkat dari sebelum dilakukan tindakan dengan setelah dilakukan tindakan.

Dalam penelitian ini, tindakan dikatakan berhasil apabila keadaan setelah tindakan lebih baik, akan tetapi apabila tidak ada bedanya atau bahkan lebih buruk, maka tindakan belum berhasil. Keadaan lebih baik yang dimaksudkan adalah jika terjadi perbaikan proses dan hasil belajar siswa setelah penerapan model pembelajaran kooperatif tipe NHT.

\section{HASIL DAN PEMBAHASAN}

Perubahan yang terjadi pada sikap siswa terhadap pembelajaran matematika diketahui dari pengamatan terhadap perilaku siswa selama proses pembelajaran berlangsung dan dicatat pada lembar pengamatan siswa pada setiap kali pertemuan. Data pada lembar pengamatan menunjukkan bahwa sikap siswa telah mengalami perubahan ke arah positif meskipun hasilnya kurang optimal. Pada awal siklus I, khususnya pada pertemuan I, siswa belum mampu mengikuti model pembelajaran ini dengan baik. Hal ini disebabkan siswa belum terbiasa dengan model pembelajaran tersebut sehingga siswa perlu beradaptasi dengan suasana baru. Keributan terjadi pada pengorganisasian kelompok dan selama siswa berdiskusi. Selain ada keributan, pembelajaran membutuhkan waktu yang agak lama untuk mengatur kelas.

Pada akhir siklus I dilaksanakan tes hasil belajar matematika setelah enam kali pertemuan. Hasil analisis menunjukan bahwa persentase siswa yang mencapai KKM adalah $14,28 \%$. Dengan demikian hasil belajar matematika siswa kelas XI IPS 5 SMA Negeri 12 Pekanbaru setelah diberikan tindakan model pembelajaran kooperatif tipe NHT pada siklus I mengalami peningkatan dibandingkan dengan hasil belajar matematika siswa sebelum tindakan, yaitu $5,7 \%$.
Setelah merefleksi hasil pelaksanaan pembelajaran pada siklus I, diperoleh suatu gambaran tindakan yang akan dilakukan pada siklus II sebagai perbaikan. Langkah-langkah model pembelajaran kooperatif tipe NHT tetap dilaksanakan dengan melakukan beberapa pengembangan dan perbaikan sesuai masalah yang ditemukan, yaitu sebagai berikut.

1. Guru harus memotivasi siswa agar lebih aktif menanggapi presentasi temannya sebagai hasil diskusi kelompok lainnya.

2. Guru harus mengarahkan siswa yang berkemampuan tinggi untuk dapat membantu temannya dalam satu kelompok yang masih belum dapat memahami materi dengan baik.

3. Guru harus menegaskan waktu diskusi dan waktu presentasi supaya sesuai dengan alokasi waktu yang telah ditetapkan.

4. Guru harus tegas dalam mengarahkan siswa yang ribut dan tidak mau belajar dalam kelompok.

5. Guru harus memperbaiki Lembar Aktifitas Siswa yang disesuaikan dengan kemampuan berpikir siswa

Pada pelaksanaan pembelajaran siklus II, terlihat bahwa perhatian, keaktivan, serta semangat siswa untuk belajar semakin memperlihatkan kemajuan setelah diterapkan model pembelajaran kooperatif tipe NHT. Ini terlihat dari keaktivan siswa memberikan respon ketika guru memberikan pertanyaan maupun keberanian dan kepercayaan diri siswa yang tampil untuk mempresentasikan hasil diskusi kelompok. Pada saat kerja kelompok, siswa yang melakukan kegiatan lain seperti ribut dan menganggu teman semakin berkurang sehingga semua kelompok dapat menyelesaikan Lembar Aktivitas Siswa dalam waktu yang telah ditentukan.

Pada akhir siklus II dilaksanakan tes hasil belajar matematika setelah empat pertemuan pembelajaran. Hasil analisis menunjukkan bahwa persentase siswa yang mencapai KKM adalah $14,28 \%$. Persentase siswa yang mencapai KKM tidak ada bedanya jika dibandingkan dengan capaian pada siklus I. Perbandingan persentase siswa yang mencapai KKM sebelum dan sesudah tindakan disajikan pada Gambar 2. 


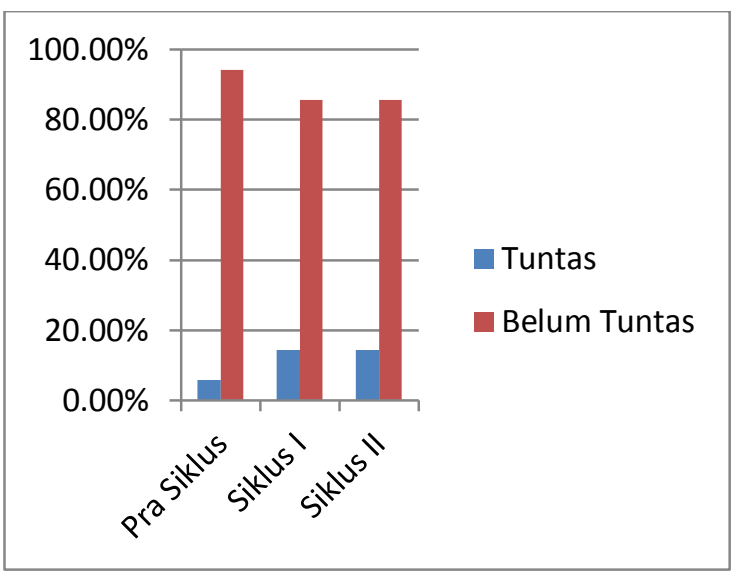

Gambar 2. Perbandingan Ketuntasan Belajar Siswa Sebelum Tindakan dan Sesudah Tindakan

Hasil belajar 35 siswa kelas XI IPS 5 SMA Negeri 12 Pekanbaru yang mengikuti pembelajaran kooperatif tipe NHT pada KD 3.8 Menjelaskan sifat-sifat turunan fungsi aljabar dan menentukan turunan fungsi aljabar menggunakan definisi atau sifat-sifat turunan fungsi, serta KD 4.8 Menyelesaikan masalah yang berkaitan dengan turunan fungsi aljabar, telah mengalami peningkatan. Persentase siswa yang mencapai KKM sebelum tindakan adalah 5,7\% sedangkan setelah tindakan (siklus I dan II) adalah $14,28 \%$. Berdasarkan kriteria keberhasilan tindakan, maka tindakan dalam penelitian ini yaitu penerapan model kooperatif tipe NHT dapat meningkatkan hasil belajar matematika siswa kelas XI IPS 5 SMAN 12 Pekanbaru.

\section{SIMPULAN}

Berdasarkan analisis data dan pembahasan hasil penelitian selama siklus I dan siklus II, dapat disimpulkan sebagai berikut.

1. Penerapan model kooperatif tipe NHT dapat meningkatkan hasil belajar matematika siswa kelas XI IPS 5 SMA Negeri 12 Pekanbaru yang diindikasikan dengan meningkatnya persentase siswa yang mencapai KKM yaitu $14,28 \%$ pada siklus I dan siklus II dibandingkan dengan hasil belajar siswa sebelum tindakan yaitu $5,7 \%$.

2. Sikap positif siswa selama pembelajaran kooperatif tipe NHT mengalami perubahan yang positif, ditunjukkan dengan meningkatnya keaktivan dalam kelompok, keberanian mengajukan pertanyaan dan kepercayaan diri dalam mempresentasikan hasil diskusi di depan kelas.

\section{DAFTAR PUSTAKA}

Arikunto, S., Suhardjono, dan Supardi. (2012). Penelitian Tindakan Kelas. Jakarta: Bumi Aksara.

Febrianto. (2018). Mendikbud Ungkap Cara Hadapi Revolusi Industri 4.0 di Pendidikan. [Online]. Tersedia: https://www.republika.co.id/berita/pendidi kan/eduaction/18/05/02/p8388c430mendikbud-ungkap-cara-hadapi-revolusi40-di-pendidikan. [3 Maret 2019].

Ibrahim dan Nur. (2000). Pembelajaran Kooperatif. Surabaya: Unesa University Press

Kemendikbud. (2016). Salinan Lampiran Permendikbud Nomor 23 Tentang Standar Penilaian Pendidikan. Kemendikbud. Jakarta.

Kiwari, B. (2018). Sri Mulyani: Matematika Diperlukan dalam Menghadapi Revolusi Industri 4.0. [Online]. Tersedia: https://kumparan.com/bandungkiwari/srimulyani-matematika-diperlukan-dalammenghadapi-revolusi-industri-4-01538271015315718945. [4 April 2019].

Kunarsih, I. dan Berlin. (2016). Ragam Pengembangan Model Pembelajaran untuk Peningkatan Profesional Guru. Jakarta: Kata Pena.

Lie, A. (2007). Cooperative Learning. Jakarta: Grasindo.

Slavin, R.E. (2010). Cooperative Learning, Teori, Riset dan Praktik. Bandung: Nusa Media.

Sudijono, A. (2009). Pengantar Statistik Pendidikan. Jakarta: Raja Grafindo Persada 